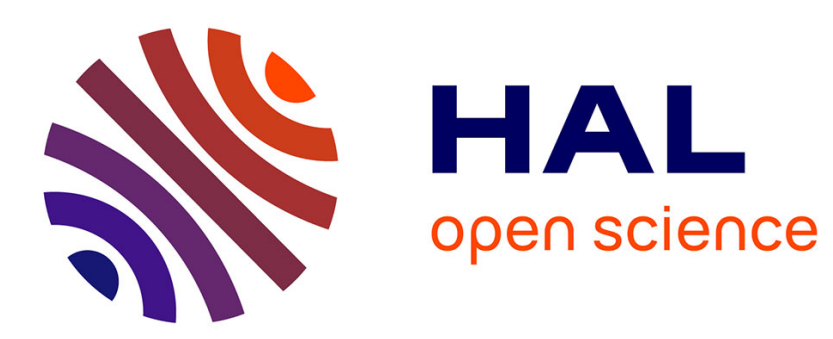

\title{
Improvement of soil properties by application of olive oil waste
}

\author{
Giovanna Cucci, Giovanni Lacolla, Leonardo Caranfa
}

\section{To cite this version:}

Giovanna Cucci, Giovanni Lacolla, Leonardo Caranfa. Improvement of soil properties by application of olive oil waste. Agronomy for Sustainable Development, 2008, 28 (4), pp.521-526. hal-00886459

\section{HAL Id: hal-00886459 \\ https://hal.science/hal-00886459}

Submitted on 1 Jan 2008

HAL is a multi-disciplinary open access archive for the deposit and dissemination of scientific research documents, whether they are published or not. The documents may come from teaching and research institutions in France or abroad, or from public or private research centers.
L'archive ouverte pluridisciplinaire HAL, est destinée au dépôt et à la diffusion de documents scientifiques de niveau recherche, publiés ou non, émanant des établissements d'enseignement et de recherche français ou étrangers, des laboratoires publics ou privés. 


\title{
Improvement of soil properties by application of olive oil waste
}

\author{
Giovanna CUCCI ${ }^{1 *}$, Giovanni LACOLLA ${ }^{1}$, Leonardo CARANFA ${ }^{2}$ \\ ${ }^{1}$ Dipartimento di Scienze delle Produzioni Vegetali, Università di Bari, Via Amendola, 165/A, 70125 Bari, Italy \\ ${ }^{2}$ Liceo Scientifico Polivalente Don Quirino Punzi, via Madonna del Soccorso, Cisternino (BR), Italy
}

(Accepted 9 August 2008)

\begin{abstract}
Wet olive pomace is an organic lignocellulosic material, a by-product of the olive milling process, a typical and traditional activity in many Mediterranean countries. Wet olive pomace has difficult commercialization due to its high moisture content of 55-65\%, that causes a noticeable increase in oil extraction costs. However, it could be conveniently reused in agriculture as a valid soil amendment to improve soil fertility and structure. Here, we studied the effects of the application of increasing amounts of non-fermented wet pomace on the fertility of a silty-clay soil, grown with 3 crops in succession: sunflower-wheat-wheat. The experiments were conducted at the Agricultural Faculty of Bari, Italy, on a Pachic Hoploxeroll soil characterized by illite and kaolinite and large amounts of Fe and Al sesquioxides. We compared the effect of wet pomace applied at amounts ranging from 0 to $210 \mathrm{Mg} \mathrm{ha}^{-1}$, incorporated 60 days prior to sunflower sowing. In the wheat late season of the second year, average samples from the $0-0.60 \mathrm{~m}$ layer were taken and tested for structural stability, organic matter, total nitrogen, available phosphorus, exchangeable potassium, $\mathrm{pH}$ and saturation extract electrical conductivity. The results indicate that the application of wet pomace induces a general improvement in soil fertility. In particular, the incorporation of increasing amounts of wet pomace improved nutrient content. For instance, an application of $210 \mathrm{Mg} \mathrm{ha}^{-1}$ of wet pomace increased soil organic matter by $+84 \%$, total $\mathrm{N} \mathrm{by}+0.90 \mathrm{~g} \mathrm{~kg}^{-1}$, available $\mathrm{P}$ by $+79.40 \mathrm{mg} \mathrm{kg}^{-1}$ and exchangeable $\mathrm{K}$ by $+80 \mathrm{mg} \mathrm{kg}^{-1}$. We also observed an improvement in soil structure, which is of particular importance in hot, arid environments and in sustainable agricultural systems.
\end{abstract}

wet pomace / soil structural stability / organic matter

\section{INTRODUCTION}

The application of organic conditioners to the soil is one of the oldest cropping techniques increasingly used to balance the constant loss of soil organic matter content (Spaccini et al., 2002; Zena et al., 2002; Hachicha et al., 2006; Saha et al., 2007). The disposal of olive oil extraction process waste is a problem for all the Mediterranean countries (Bonari and Ceccarini, 2000), traditionally related to vegetable water (Paris, 1998; Montemurro et al., 2004), which is currently substituted by the disposal of wet pomace (Casa et al., 2001). This agro-industrial waste could instead represent a strategic resource in the integrated management of the agricultural system, as it would meet the twofold objective of evacuating olive oil waste and using it beneficially to improve soil fertility (Ceccon, 2001).

Wet olive pomace is an organic lignocellulosic material, a by-product of the olive milling process, a typical and traditional activity in many Mediterranean countries. At present, the product has difficult commercial collocation due to its

* Corresponding author: giovanna.cucci@agr.uniba.it high moisture content (55-65\%), which causes a noticeable increase in oil extraction costs, but it could be conveniently reused in agriculture as a valid soil amendment (L. 574/96). The maximum amount of wet pomace that farmers may apply over a 3 year period is $210 \mathrm{Mg} \mathrm{ha}^{-1}$. Therefore, farmers have three possible alternative solutions: the application of $210 \mathrm{Mg} \mathrm{ha}^{-1}$ of waste once every 3 years; the application of $2 / 3$ of the maximum amount $\left(140 \mathrm{Mg} \mathrm{ha}^{-1}\right)$ in the first year and $1 / 3\left(70 \mathrm{Mg} \mathrm{ha}^{-1}\right)$ in the second year; or the application of $1 / 3$ of the maximum amount every year. In Italy, where the soil organic matter content is on average low and the Mediterranean climate contributes to its fast mineralization, the spreading of wet pomace on agricultural soil could increase its fertility; moreover, crops could also benefit from the dissolved water and nutrients without toxic effects or yield reductions (Bonari and Ceccarini, 1993; Papini et al., 2000). Nevertheless, the same as vegetable water, wet pomace has some inconveniences when it is used in agriculture. The first is the difficulty to uniformly incorporate it into the soil. The second is its toxicity to plants due to the presence of high amounts of polyphenols (Rice, 1979; Lynch, 1980; Marambe and Ando, 1992) which have, however, a fast decay (Riffaldi et al., 1990; Camacho 
et al., 2000), and of oil residues that induce a slowing of the metabolism and of zymogene soil microflora multiplication (Oliver, 1993), attenuated for some physiological groups after about 30 days, but continuing until 300 days for other groups such as autotrophic nitrifiers (Bedini et al., 1998). The spreading of olive-processing wet pomace on the soil seems, however, to improve the soil physical fertility. In particular, it induces an increase in the storage and transmission pores with beneficial effects on water retention, water flow in the soil and the structural stability, with the subsequent prevention of surface crusting (Bonari et al., 2001). The reductions of macroporosity and water infiltration in the soil just after treatments are temporary unless applications are very high and/or take place in periods in which the biological activity is low, like in winter. It is known that the soil structural quality mostly depends on its interaction with organic matter, in the sense that the accumulation of the latter contributes to the formation and subsequent stabilization of aggregates against the dispersing action of water (Angers and giroux, 1996; Piccolo, 1996; Spaccini et al., 2001; Cavazza et al., 2002). Moreover, the soil salinization risk needs further studies, although it might presumably become a problem only if wet pomace is applied on soils that are already saline. However, both the increase in salinity and alterations in the soil $\mathrm{pH}$ are temporary and, in general, are not detectable after a maximum period of three months from the application of olive waste. More lasting variations concern instead the content of organic matter, phosphorus and potassium, and the immobilization of nitrogen in the soil, so that olive residues are considered as slow-acting fertilizers (Bonari et al., 2001). The indications reported in the literature on the modifications of the physico-chemical characteristics of soils conditioned by olive residues are still incomplete and only allow a partial assessment of the problem. To provide an additional contribution to the subject, this research was undertaken with the purpose of assessing the effects of the incorporation of increasing amounts of non-fermented wet pomace on some fertility parameters of a Southern Italian silty-clay soil grown with three crops in rotation.

\section{MATERIALS AND METHODS}

The research was carried out in the period 2002-2004 in the experimental field next to the Faculty of Agriculture of Bari University, Italy, within a long-term trial aiming to assess the cumulative effect of the incorporation of increasing amounts of wet pomace on soil fertility and on crops in rotation: sunflower-wheat-wheat. Crops were grown in pots of 0.72 and $0.60 \mathrm{~m}$ in width and height, located outdoors and filled with about $293 \mathrm{~kg}$ of silty-clay textured soil rich in iron and aluminium sesquioxides, whose main chemical and physical characteristics at the beginning of the experiment are reported in Table I.

Using a randomized block experimental design with 6 replicates, the trial involved the comparison of the application of 8 amounts of wet pomace with $55.8 \%$ moisture (0-0.71.4-2.9-4.3-5.7-7.2-8.6 $\mathrm{Kg} \mathrm{pot}^{-1}$ corresponding, respectively, to $0-17.5-35-70-105-140-175-210 \mathrm{Mg} \mathrm{ha}^{-1}$ ), taken from an
Table I. Main properties of the soils treated by wet pomace. ECe: electrical conductivity of the saturation extract; ESP: Exchangeable Sodium Percentage; CEC: Cation Exchange Capacity.

\begin{tabular}{|c|c|c|}
\hline \multicolumn{3}{|l|}{ Chemical properties: } \\
\hline \multicolumn{2}{|c|}{ Total Nitrogen ( Kjeldahl meth.) $\left(\mathrm{g} \mathrm{kg}^{-1}\right)$} & 1.65 \\
\hline \multicolumn{2}{|c|}{ Available phosphorus (Olsen meth.) (mg kg $\left.{ }^{-1}\right)$} & 32.50 \\
\hline \multicolumn{2}{|c|}{ Exchang. Potassium (barium clor. meth.) $\left(\mathrm{mg} \mathrm{kg}^{-1}\right)$} & 240.00 \\
\hline \multicolumn{2}{|c|}{ Organic matter (Walkley Black meth.) (g $100 \mathrm{~g}^{-1}$ ) } & 2.06 \\
\hline \multicolumn{2}{|c|}{ Total limestone $\left({\left.\mathrm{g} 100 \mathrm{~g}^{-1}\right)}^{2}\right.$} & 2.58 \\
\hline \multicolumn{2}{|c|}{ Active limestone $\left({\left.\mathrm{g} 100 \mathrm{~g}^{-1}\right)}\right.$} & 1.40 \\
\hline \multicolumn{2}{|c|}{$\mathrm{pH}\left(\mathrm{pH}\right.$ in $\left.\mathrm{H}_{2} \mathrm{O}\right)$} & 7.18 \\
\hline \multicolumn{2}{|l|}{$\mathrm{ECe}\left(\mathrm{dS} \mathrm{m}^{-1}\right)$} & 0.78 \\
\hline \multicolumn{2}{|l|}{ ESP } & 0.80 \\
\hline \multicolumn{2}{|c|}{$\mathrm{CEC}\left(\mathrm{BaCl}_{2}\right.$ meth $)(\mathrm{meq} / 100 \mathrm{~g}$ of dry soil $)$} & 31.61 \\
\hline \multicolumn{3}{|c|}{ Particle-size analysis (mm): } \\
\hline \multicolumn{2}{|c|}{ 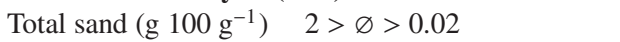 } & 20.94 \\
\hline \multicolumn{2}{|c|}{ Silt $\left(\mathrm{g} 100 \mathrm{~g}^{-1}\right) \quad 0.02>\varnothing>0.002$} & 44.00 \\
\hline Clay $\left(\mathrm{g} 100 \mathrm{~g}^{-1}\right)$ & $\varnothing<0.002$ & 35.06 \\
\hline \multicolumn{3}{|c|}{ Hydrological properties: } \\
\hline \multicolumn{2}{|c|}{ Field capacity (field determ.) ( $\%$ dry weight) } & 35.80 \\
\hline \multicolumn{2}{|c|}{ Wilting point (-1.5 $\mathrm{MPa})$ (\% dry weight) } & 18.40 \\
\hline \multicolumn{2}{|c|}{ Bulk density $\left(\mathrm{kg} \mathrm{dm}^{-3}\right)$} & 1.20 \\
\hline
\end{tabular}

Table II. Physico-chemical properties of applied wet pomace. (Values on dry weight)

\begin{tabular}{|c|c|}
\hline $\mathrm{pH}$ & 5.15 \\
\hline Moisture (g $\left.100 \mathrm{~g}^{-1}\right)$ & 55.80 \\
\hline 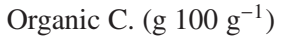 & 51.77 \\
\hline Phenols ( $\left.\mathrm{mg} \mathrm{g}^{-1}\right)$ & 12.37 \\
\hline Fats $\left(\mathrm{g} 100 \mathrm{~g}^{-1}\right)$ & 10.93 \\
\hline Total N (g $\left.100 \mathrm{~g}^{-1}\right)$ & 1.18 \\
\hline Total P (g $\left.100 \mathrm{~g}^{-1}\right)$ & 0.15 \\
\hline Total K $\left({\left.\mathrm{g} 100 \mathrm{~g}^{-1}\right)}^{1}\right.$ & 1.03 \\
\hline $\mathrm{Zn}\left(\mathrm{mg} \mathrm{kg}^{-1}\right)$ & 20.00 \\
\hline $\operatorname{Mn}\left(\mathrm{mg} \mathrm{kg}^{-1}\right)$ & 10.00 \\
\hline $\mathrm{Cu}\left(\mathrm{mg} \mathrm{kg}^{-1}\right)$ & 1000 \\
\hline $\mathrm{Cr}, \mathrm{Ni}, \mathrm{Co}, \mathrm{Pb}, \mathrm{Cd}$ & Absent \\
\hline
\end{tabular}

oil-mill and applied to a soil in the winter season preceding the planting of sunflower. The main physico-chemical properties of wet pomace are reported in Table II.

Once spread, the waste was immediately incorporated into the soil; about two months after its application, the seedbed was prepared for sunflower sowing. During the wet pomace incorporation, the soil was mixed several times in order to obtain a uniform distribution of the product. This confirmed some inconveniences, also reported by other authors (Rice, 1979; Lynch, 1980; Marambe and Ando, 1992), and the applied waste did not mix easily into the soil; indeed, pomace particles were still evident on the surface of treated pots for a long time. Sunflower, cv. HS, characterized by a high oleic content, was sown at the end of April 2002, whereas the two subsequent crops of durum wheat were sown, using, respectively, cv. Simeto in the first year and cv. Colosseo in the second year, on January and November 2003.

Just after seeding, to favor seed germination and plantlet emergence, crops were irrigated with tap water, bringing only 

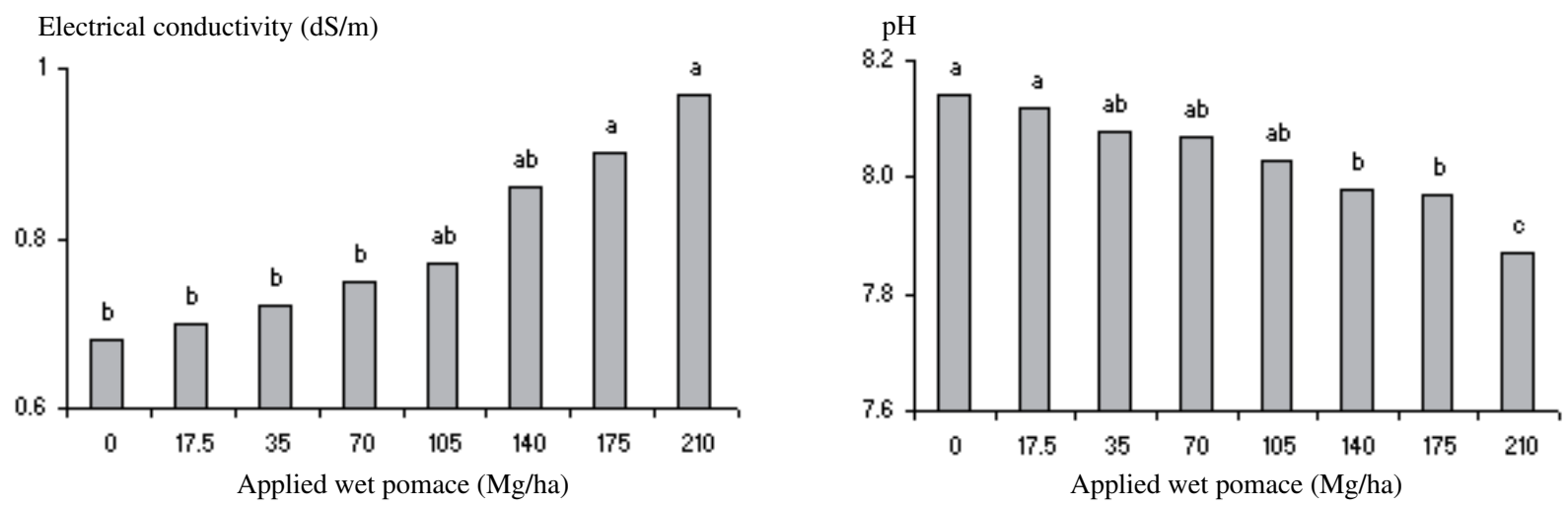

Figure 1. Variation in electrical conductivity (ECe) and $\mathrm{pH}$ in the soil conditioned by increasing amounts of wet pomace. For each effect considered, the values followed by the same letter are not significantly different, according to the SNK test at $P \leqslant 0.05$.

the shallow soil layer $(0.20 \mathrm{~m})$ to field capacity. From plantlet emergence until the end of the irrigation season, irrigation was applied whenever $30 \%$ and $50 \%$ of the maximum available water were lost by evapotranspiration, respectively, for sunflower and wheat crops, applying the volume required to bring the whole soil mass contained in each pot to field capacity. All local farming practices were applied. At the end of the threeyear rotation, a mean soil sample was taken from each pot, along the $0-0.60 \mathrm{~m}$ profile, and tested, following the methodologies (Violante, 2000), for the electrical conductivity and $\mathrm{pH}$ of the saturated paste, the organic matter $(\mathrm{OM})$, total nitrogen $(\mathrm{N})$, available phosphorus $(\mathrm{P})$, exchangeable potassium $(\mathrm{K})$, structural stability and hydrological constants. All data were then submitted to analysis of variance using the SAS software (S.A.S. INSTITUTE INC.-USA), and the differences between the means were assessed by the Student-Newman-Keuls test. The most significant results are reported in Figures 1 to 5.

\section{RESULTS AND DISCUSSION}

Based on the results of the analyses of the soil, sampled three years after the application of increasing amounts of wet pomace, just after the harvest of the second year wheat, some positive effects of this conditioner were observed on the soil's physico-chemical properties.

\section{1. $\mathrm{pH}$ and the conductivity of the saturation extract}

It may be stated that the application of increasing amounts of wet pomace, whose reaction is definitely acid ( $\mathrm{pH}$ 5.5), seems to induce a moderate lowering of the soil $\mathrm{pH}$, especially at the highest rate $(\mathrm{pH} 8.14$ of the control and 7.87 with the application of the highest residue amount), presumably due to the high buffer power of the soil, in accordance with Cucci et al. (2003). The electrical conductivity of the saturation extract, which reflects the soil solution salinity, although low, increases with the growing amounts of applied residues (Fig. 1). For instance, electrical conductivity increases from $0.68 \mathrm{dS} \mathrm{m}^{-1}$ for the untreated soil to $0.97 \mathrm{dS} \mathrm{m}^{-1}$ for the soil amended with $210 \mathrm{Mg} \mathrm{ha}^{-1}$ of wet pomace.

\subsection{Organic matter and total nitrogen}

Three years after the application of wet pomace on the soil, a significant positive difference was observed, both for the amount of cumulated organic matter and the total nitrogen content, which mostly reflected the organic matter values. The higher content of both is related to the amount of residue applied; comparing the control $\left(0 \mathrm{Mg} \mathrm{ha}^{-1}\right.$ of wet pomace) with the soil conditioned by $210 \mathrm{Mg} \mathrm{ha}^{-1}$ of waste, OM

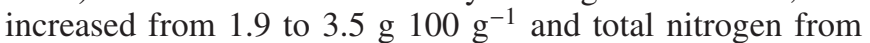
1.17 to $2.07 \mathrm{~g} \mathrm{~kg}^{-1}$, in accordance with Bonari et al. (2001). (Fig. 2).

\subsection{Available phosphorus and exchangeable potassium}

Based on the results achieved it seems that the application of increasing amounts of wet pomace on the soil shows a positive effect on phosphorus and potassium, in terms of fertilizing value. Both elements were shown to increase with higher amounts of applied conditioner. In particular, comparing the control $\left(0 \mathrm{Mg} \mathrm{ha}^{-1}\right.$ of wet pomace $)$ with the soil conditioned by the highest amount of olive waste $\left(210 \mathrm{Mg} \mathrm{ha}^{-1}\right.$ of wet pomace), available phosphorus increased from 33.6 to $113 \mathrm{~m} \mathrm{~kg}^{-1}$, whereas exchangeable potassium increased from 273 to $353 \mathrm{mg} \mathrm{kg}^{-1}$ (Fig. 3).

\subsection{Structural stability and hydrological constants}

The organic matter build-up in the soil due to the application of increasing amounts of wet pomace contributed to the formation and subsequent stabilization of the aggregates against the dispersing action of water. The soil structural stability measured on 1-2 $\mathrm{mm}$ aggregates following the water sieving criterion with or without alcohol pre-treatment (according to Hénin and Monnier, 1956) showed a progressive increase in the structural stability index of the aggregates through the mean soil profile, as the applied wet pomace amount was increased. The structural stability indices increased - comparing the soil not conditioned by olive residue 

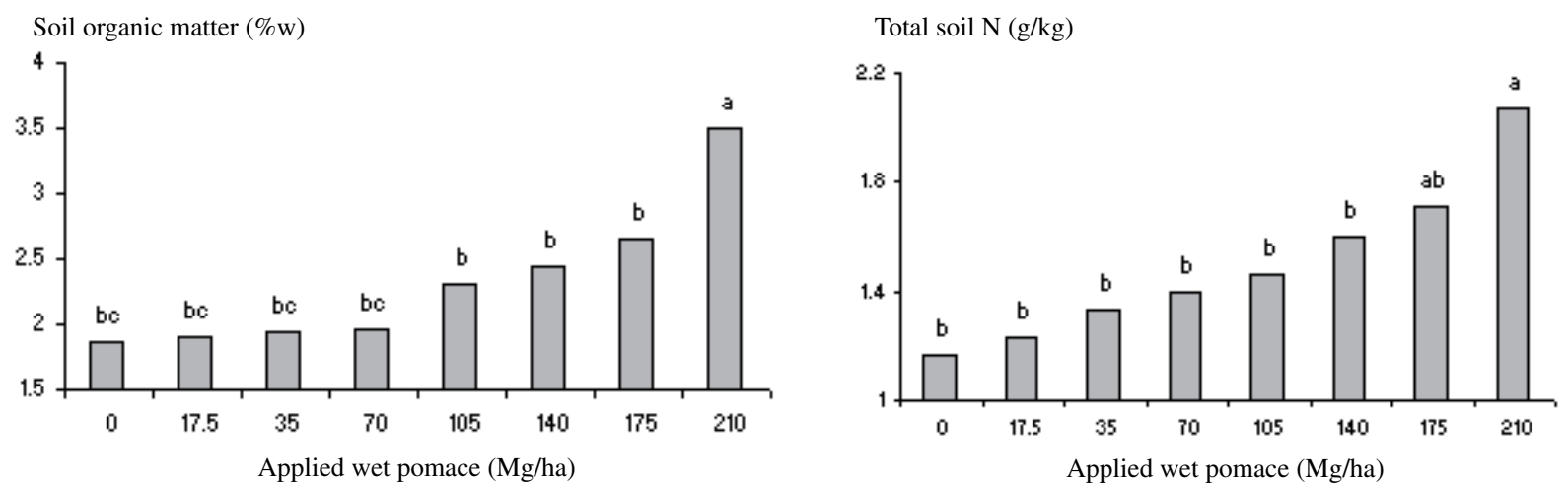

Figure 2. Variation in organic matter and total nitrogen in the soil conditioned by increasing amounts of wet pomace. OM: organic matter. For each effect considered, the values followed by the same letter are not significantly different, according to the SNK test at $P \leqslant 0.05$.
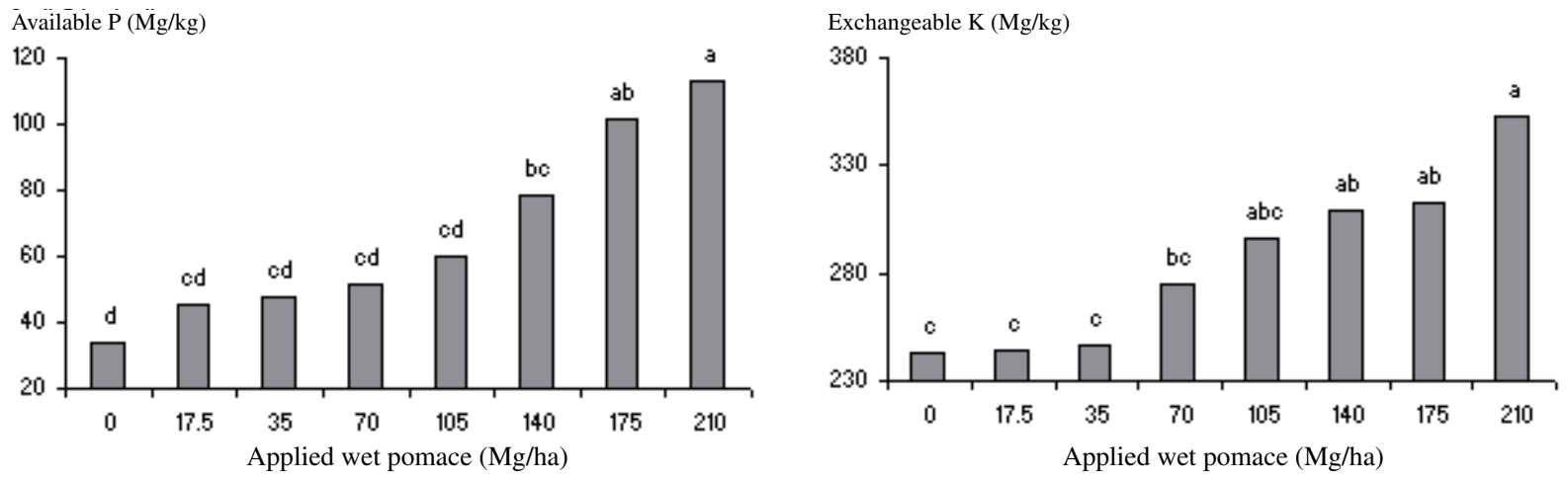

Figure 3. Variation in available phosphorus and exchangeable potassium in the soil conditioned by increasing amounts of wet pomace. For each effect considered, the values followed by the same letter are not significantly different, according to the SNK test at $P \leqslant 0.05$.

with the soil submitted to the highest amount $\left(210 \mathrm{Mg} \mathrm{ha}^{-1}\right)$ - respectively, from 38.6 to $50.6 \%$ without pre-treatment and from 55.7 to $71 \%$ with alcohol pre-treatment (Fig. 4).

Low structural stability in non-pre-treated samples is associated with a good stability after alcohol pre-treatment: the former result represents the soil surface status (beating rainfall effect), whereas the latter expresses the effect under the soil surface (Cavazza et al., 2002). Comparing the soil not conditioned by wet pomace with the soil treated by $210 \mathrm{Mg} \mathrm{ha}^{-1}$ of waste, the percent moisture on dry soil at field capacity $(-0.3 \mathrm{bar})$ and at the wilting point $(-15 \mathrm{bar})$ changed, respectively, from 26.1 to $28.7 \%$ and from 18.4 to $20.5 \%$, whereas the available water increased from 7.7 to 8.2 (Fig. 5).

The increase in organic matter caused by the application of increasing amounts of wet pomace was shown to have a beneficial effect on the structural stability, especially on red soils, although the organic matter's ability to bind with iron and aluminium sesquioxides could produce a harmful effect, presumably because it reduces the free fractions of iron and aluminium. An excess of calcium and magnesium carbonates has a depressing effect on the structural stability; illite and kaolinite have instead a major role in stabilizing the structure, notably in soils rich in sesquioxides (Cavazza et al., 2002). The application of increasing amounts of wet pomace to the soil, in accordance with Casa et al. (2001), also induced an increase in the percent moisture of dry soil corresponding to field capacity and wilting point, without significant statistical differences in terms of available water as compared with the control. Even in a volcanic soil of the Upper Latium region (Italy), Casa et al. (2001) did not find any change in the available water as influenced by a variation in the applied olive waste. An ample experimental literature has confirmed that the application of organic matter to the soil improves its water-holding ability at field capacity and wilting point (Carter and Steward, 1996; Haynes and Naidu, 1998). This effect might be related to the increase in the soil microporosity that could have induced higher water-holding capacity (Loveland and Webb, 2003). Moreover, a satisfactory soil organic matter supply ensures a better plant nutrition, and influences in particular the nutrient availability thanks to its chelating action that allows nutrients to be retained in the cultivated layer in the available form. Hence the modifications induced by olive waste on some soil chemical properties, as compared with the starting conditions, have been shown to be positively significant. Total N, available $\mathrm{P}$ and exchangeable $\mathrm{K}$ were found in greater amounts, as influenced by the incorporation of wet pomace, that did not, however, jeopardize the original chemical and physical soil properties. These effects of soil conditioner spreading play a significant role in improving water storage capacity and reducing the risk of nutrient leaching. The use of wet pomace 


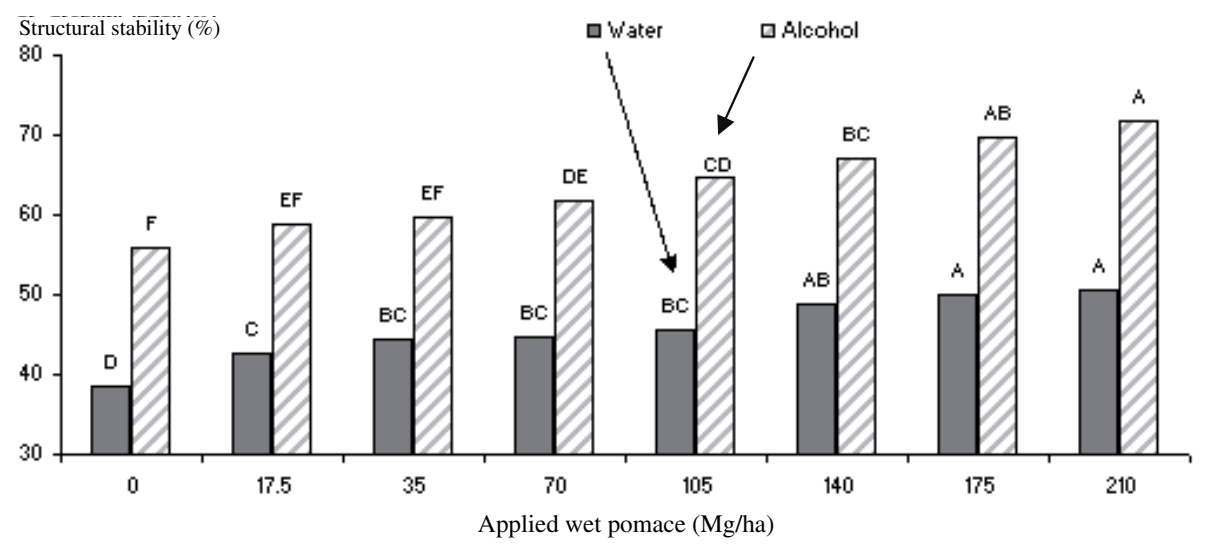

Figure 4. Variation in the structural stability index in the soil conditioned by increasing amounts of wet pomace. For each effect considered, the values followed by the same letter are not significantly different, according to the SNK test at $P \leqslant 0.01$.

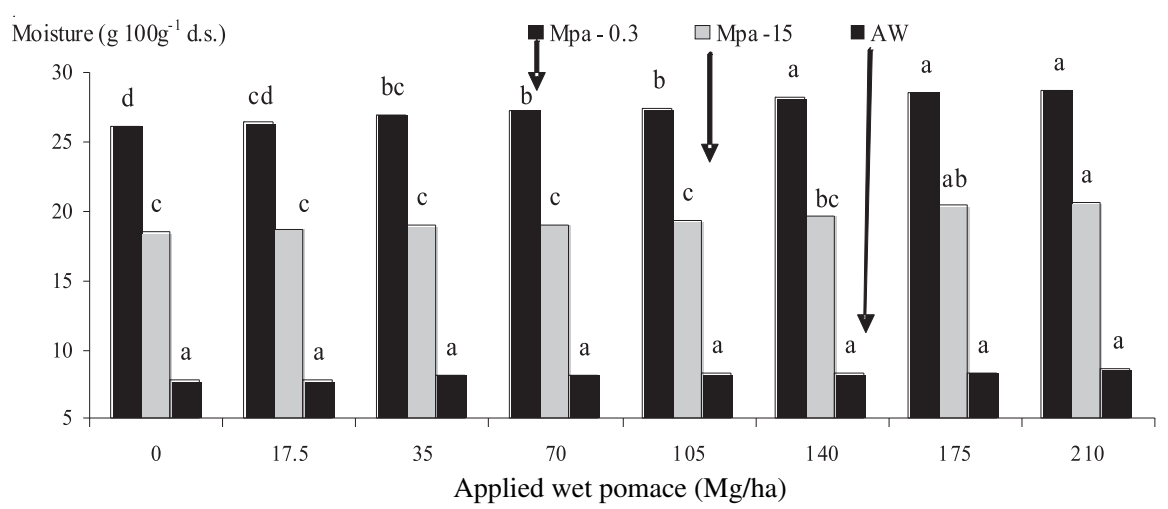

Figure 5. Variation in percent moisture of dry soil at field capacity and at the wilting point, available water in the soil conditioned by increasing amounts of wet pomace. d.s.: dry soil; Mpa: Mega Pascal; AW: available water. For each effect considered, the values followed by the same letter are not significantly different, according to the SNK test at $P \leqslant 0.05$.

might contribute to increasing water and fertilizer-use efficiency, which is extremely important in hot, dry environments and in sustainable farming systems.

\section{CONCLUSION}

Soil application of wet pomace, a lignocellulosic organic material, a by-product of the olive milling process, allows an overall fertility improvement. Soil organic matter and nutrient content increased without altering $\mathrm{pH}$ and salinity; moreover, soil structure improved significantly. In comparison with the control treatment, with the application of $210 \mathrm{Mg} \mathrm{ha}^{-1}$ of wet pomace an increment in organic matter $(84 \%)$, total $\mathrm{N}$ $\left(0.90 \mathrm{~g} \mathrm{~kg}^{-1}\right)$, available $\mathrm{P}\left(79.4 \mathrm{mg} \mathrm{kg}^{-1}\right)$ and exchangeable $\mathrm{K}\left(80 \mathrm{mg} \mathrm{kg}^{-1}\right)$ was recorded. Moreover, the application of wet pomace to the soil increased the structural stability index of the aggregates, favoring soil particle aggregation, that is extremely important for our soils, characterized on average by low organic carbon contents. The highest waste applications also induced an increase in the percent moisture at field capacity and at the wilting point, showing a trend towards an increase in the available water. Therefore, the experimental results highlight the opportunity of the agronomic use of this agro-industrial by-product, because it can be considered a strategic resource for integrated agricultural management, including agro-industrial waste disposal and the agronomic valorization of the organic materials.

Acknowledgements: Research supported by Ateneo ex $60 \%$ funds. Head of research: Prof. Giovanna Cucci.

\section{REFERENCES}

Angers D.A., Giroux M. (1996) Soil Sci. Soc. Am. J. 60, 1547-1551.

Bedini S., Privitera I., Filippi C., Nuti M.P. (1998) Evoluzione del microbiota in terreni ammendati con sanse umide non fermentate, Riv. Agron. 32, 264-270.

Bonari E., Ceccarini L. (1993) Sugli effetti dello spargimento delle acque di vegetazione sul terreno agrario: Risultati di una ricerca sperimentale, Genio Rurale 5, 60-67.

Bonari E., Ceccarini L. (2000) Effetti della distribuzione di dosi crescenti di sanse umide sul terreno agrario, in: Smaltimento e riutilizzo dei reflui dei frantoi. A.R.S.I.A. Regione Toscana, Effeemme Lito Srl, Firenze, Italy, pp. 31-57. 
Bonari E., Ceccarini L., Giannini C. (2001) Studio degli effetti della distribuzione dei reflui di frantoio (AV.) in diversi terreni coltivati a soia, Proceedings of the XXXIV Congress of the Italian Society of Agronomy, 17-21 September, Pisa, Italy, pp. 97-98.

Carter M.R., Stewart B.A. (1996) Structure and organic matter storage, Agricultural Soils. Ed., CRC press, Boca Raton.

Casa R., D’Annibale A., Pieruccetti F., Giovannozzi Sermanni G., Locascio B. (2001) Abbattimento della componente fenolica in reflui oleari: effetti sulla germinabilità del frumento duro, Proceedings of the XXXIV Congress of the Italian Society of Agronomy, 17-21 September, Pisa, Italy, pp. 19-20.

Cavazza L., Patruno A., Cirillo E. (2002) Soil trait and structure stability in artificial sodicated soil, Ital. J. Agron. 6, 15-25.

Ceccon P. (2001) Effetti agronomici e ambientali dell'applicazione di acque di vegetazione al frumento, Proceedings of the XXXIV Congress of the Italian Society of Agronomy, 17-21 September, Pisa, Italy, pp. 47-48.

Camacho C.B., Torres J.G., Fernandez J.L.G. (2000) Influencia de la humedad en la evolucion de parametros uimicos de un suelo tras la adicion de alperujo, Edafologia 7, 215-220.

Cucci G., Rubino P., Caliandro A. (2003) Effects of irrigation water with different salt concentrations and SAR values on soil salinization and sodification, Ital. J. Agron. 7, 41-48.

Hachicha S., Chtourou M., Medhioub K., Ammar E. (2006) Compost of poultry manure and olive mill wastes as an alternative fertilizer, Agron. Sustain. Dev. 26, 135-142.

Hénin S., Monnier G. (1956) Évaluation de la stabilité de la structure du sol, 6th Int. Soil. Sci. Congr. Proc. Vol. B, pp. 49-52.

Hénin S., Grass R., Monnier G. (1969) Le profile cultural, Masson et Cie., Paris.

Haynes R.J., Naidu R. (1998) Influence of lime, fertilizer and manure applications on soil organic content and soil physical conditions: a review, Nutr. Cycl. Agroecosys. 51, 123-137.

Loveland P., Webb J. (2003) Is there a critical level of organic matter in the agricultural soils of temperature regions: a review, Soil Till. Res. 70, $1-18$.
Lynch J.M. (1980) Effects of organic acids on the germination of seeds and growth of seedlings, Plant Cell Environ. 3, 255-259.

Marambe B., Ando T. (1992) Phenolic acids as potential seed germination inhibitors in animal waste composts, Soil Sci. Plant Nutr. 38, 727733.

Montemurro F., Convertini G., Ferri D. (2004) Mill wastewater and olive pomace composta amendments for rye-grass, Agronomie 24, 481486.

Oliver J.D. (1993) Formation of viable but noncolture cell. In: Starvation of Bacteria, in: Kjelleberg S. (Ed.), Plenum Press, New York, pp. 239-272.

Papini R., Pellegrini S., Vignozzi N., Pezzarossa B., Pini R., Ceccarini L., Pagliai M., Bonari E. (2000) Impatto dello spandimento di reflui oleari su alcune caratteristiche chimiche e fisiche del suolo. Atti XVIII Convegno Nazionale della Società Italiana di Chimica Agraria, 20-22 September, Catania, Italy, pp. 226-234.

Paris P. (1998) Aspetti agronomici dell'impiego dei reflui dell'industria agro-alimentare, Riv. Agron. 32, 196-220.

Rice E.L. (1979) Allelopathy, Bot. Rev. 45, 15.

Piccolo A. (1996) Humus and soil conservation, in: Piccolo A. (Ed.), Elsevier, Amesterdam, pp. 225-264.

Riffaldi R., Saviozzi A., Levi-Minzi R. (1990) Retention of coumaric acid by soil and its colloidal components, WA.S.P. 51, 307-315.

Saha S., Pandey A.K., Gopinath K.A., Bhattacharaya R., Kundu S., Gupta H.S. (2007) Nutritional quality of organic rice grown on organic composts, Agron. Sustain. Dev. 27, 223-229.

Spaccini R., Zena A., Igwe C.A., Mbagwu J.S.C., Piccolo A. (2001) Biogeochemistry 53, 1-22.

Spaccini R., Piccolo A., Mbagwu J.S.C., Zena A., Igwe C.A. (2002) Soil use and management, 18, 404-411.

Violante P. (2000) Metodi di analisi chimica del suolo, Franco Angeli.

Zena A., Fagnano M., Merla G., Piccolo A., Quaglietta Chiarandà F. (2002) Proceedings of 7th congress of the European Society for Agronomy, 15-18 July, Còrdoba, Spain. 